\title{
Aspects of Competence-Based Education as Footholds to Improve the Connectivity Between Learning in School and in the Workplace
}

\author{
Renate Wesselink • Cees de Jong • \\ Harm J. A. Biemans
}

Received: 1 December 2008 / Accepted: 29 September 2009 /

Published online: 23 October 2009

(C) The Author(s) 2009. This article is published with open access at Springerlink.com

\begin{abstract}
Recent developments in competence-based education have motivated institutions of vocational education and training (VET) to improve the links or connectivity between learning in school and learning in the workplace, which has been a problem for decades. In previous research, a theoretical framework describing the underlying aspects of competence-based education was developed. In this study, three aspects of this framework were used to analyse connectivity between learning in school and learning in the workplace. These aspects were: i) authenticity, ii) selfresponsibility, and iii) the role of the teacher as expert and coach. Three stakeholder groups (i.e., students, teachers, and workplace training supervisors) involved in secondary VET programs in the field of life sciences in the Netherlands were questioned on these aspects. Based on their interviews, it is concluded that these aspects provide information about the process of connectivity. Because stakeholder groups hold different conceptions of workplace learning and often do not communicate adequately about mutual responsibilities, the implementation of these aspects of competence-based education has not significantly improved the connectivity situation. Nevertheless, these aspects of competence-based education can guide stakeholder groups in making clearer agreements about mutual responsibilities, which may improve connectivity in the future.
\end{abstract}

\footnotetext{
R. Wesselink $(\bowtie) \cdot$ H. J. A. Biemans

Department Social Sciences, Wageningen University, P.O. Box 8130, 6700 EW Wageningen,

The Netherlands

e-mail: renate.wesselink@wur.nl

H. J. A. Biemans

e-mail: harm.biemans@wur.nl

C. de Jong

CPS Education Development and Advice, P.O. Box 1592, 3800 BN Amersfoort, The Netherlands e-mail: c.dejong@cps.nl
} 
Keywords Competence-based education · Workplace learning $\cdot$ Connectivity $\cdot$ Life sciences

\section{Competence-Based Education and the Dutch Vocational Education}

Implementation of competence-based education has become a major trend in Dutch vocational education over the last decade (Biemans et al. 2004; Wesselink et al. 2007). This trend extends to all educational programs and fields of study and has been stimulated by governmental policy. This development in competence-based education is not only evident in the Netherlands, as many other countries within Europe and beyond are now taking up this approach (for more details see Arguelles and Gonczi 2000; Mulder et al. 2007; Mulder 2007; Brockmann et al. 2008; Biemans et al. 2009). The life sciences sector, which provides the context for the discussion within this paper, is no exception to this trend in the Dutch educational landscape. In 2007, more than 70,000 students were enrolled in educational programs in life sciences delivered by institutions in the Netherlands. These programs focus on agricultural domains (e.g., plant and animal sciences) as well as relatively new fields in life sciences (e.g., nutrition, health, nature, and the living environment). Educational programs in life sciences are offered at all levels of vocational and higher education: preparatory vocational education, secondary vocational education, higher vocational education, university education, and postgraduate (adult) vocational education. Due to government policy, in the next few years, educational programs at all these levels will be increasingly characterised by the use of competencies for the development of their curriculum. For preparatory vocational education, a competence-based examination is being prepared, and integrated thematic learning domains will also be introduced. In secondary vocational education (SVET), a competence-based qualification structure is being implemented and is guiding the design of competence-based learning activities and assessment procedures. Institutions for higher vocational education are also making their educational concepts more competence-based. This is also the case, to some extent, at Wageningen University, the Dutch university in the life sciences. A key goal of competence-based education is to prepare future professionals so that they will be able to contribute to the advancement of the life sciences sector, towards more sustainable production methods. Moreover, competence-based educational programs aim also to contribute to the students' (professional) identity development. Finally, students who finish their educational programs should be better prepared not only for working in professional practice but also for participating in society as a whole (cf. Jenewein et al. 2002).

To realise these educational goals, a strong connection between education and the (regional) labour market is necessary (Biemans et al. 2004). Competencies are directly derived from professional practice, and competence-based education implies the integrated development of knowledge, attitudes, and skills (i.e., the elements of competence) in relation to job-specific core tasks. So, learning in the workplace is becoming more important (Van den Berg and De Bruijn 2009) and should be enacted in collaboration with private and public organisations and/or enterprises. Securing an effective balance between learning in school and learning in the workplace is crucial for the success of competence-based education to achieve these kinds of goals. 
In this article, the findings of a study on the interrelation between competencebased education, on the one hand, and the connectivity between learning in school and learning in the workplace on the other will be presented and discussed. In the following section, the concept of competence-based education will first be elaborated. Following this, issues of connectivity between learning in school and learning in the workplace will be described, followed by a discussion about the central research question. After the research method and results are described, conclusions will be formulated as to how aspects of competence-based education can be used as footholds to improve the connectivity between learning in school and learning in the workplace. In all, this paper argues that a successful provision of competence-based education is founded on a strong connectivity between what occurs in educational institutions and workplace settings.

\section{Competence-Based Education}

Competence-based education is often used as a catch-all term comprising many different forms of education (Van der Klink et al. 2007). Yet, it is a complex educational innovation that combines several conceptual notions in contemporary education with its own particular characteristics (e.g., authentic learning, integration of theory and practice, validation of prior learning) and new theories on learning such as self-regulation theory and (social) constructivism (Mulder et al. 2007). Studies that examine these aspects together are scarce (De Bruijn et al. 2005). However, several studies focus specifically on the content of competence-based curricula, such as on critical thinking competence for citizenship (Ten Dam and Volman 2004), problem-solving competence for eighth-graders (Perels et al. 2005), and in-service competence for teachers (Brouwer and Korthagen 2005). There are also examples of scholars who study instructional aspects of competence-based education. Perels et al. (2005), for example, conclude in their research that the combination of self-regulatory and problem-solving strategies is most effective in terms of improvement of self-regulatory competencies. Studies on authentic assessments suggest that when students perceive that assessment tasks resemble their future professional practice (i.e., perceive the tasks as authentic), they are motivated to study more intensively and develop more generic competencies (Gulikers 2007). Finally, electronic learning environments can stimulate competence development; students are enabled to work together and the teachers are capable of acting as coaches because they can closely follow the learning process of the students (Bastiaens and Martens 2003). Each of these studies addresses a particular aspect of how competence development can be fostered.

Thus, both the 'what' (i.e., curriculum) and 'how' (i.e., instruction) questions appear to be relevant for evaluating the provision of competence-based education (Wesselink et al. 2007). The first question is 'what' competencies (content of the curriculum) are necessary to function in a job or in society and the second question is 'how should' these competencies be fostered (i.e., instruction). Wesselink et al. (2007) developed a theoretical framework that integrates both the underlying curriculum aspects and the instructional aspects of competence-based education and that is based on a Delphi study involving Dutch educational researchers in the 
domain of competence-based education. The aspects of competence-based education labelled Aspect 1, 2, 5, and 8 in this framework focus specifically on the content of a study program, while the remaining four aspects focus specifically on the instructional features:

Aspect 1 The competencies that are the basis for the study program are defined

Aspect 2 Core professional problems are the organising unit for designing or redesigning the curriculum (learning and assessment)

Aspect 3 Competence development of students is assessed before, during, and after the learning process

Aspect 4 Learning activities take place in various authentic situations

Aspect 5 Knowledge, skills, and attitudes are integrated in learning and assessment processes

Aspect 6 Self-responsibility and (self-)reflection of students are stimulated

Aspect 7 Teachers, both in school and in the workplace, balance their roles as coaches and experts

Aspect 8 A basis is established for a lifelong learning attitude among students

At this point, it should be noted that it is a combination of the above aspects that defines comprehensive competence-based education (Biemans et al. 2009; see also the following paragraphs). The separate aspects (referring to rather general teaching and learning approaches) are not unique to competence-based education (e.g., Aspect 6 on stimulating self-responsibility and (self-) reflection).

As described in detail by Biemans et al. (2004, 2009); Stoof et al. (2002) and Mulder (2004, 2007), the concepts of competence and competence-based education have a long history in the fields of education and training. The approach of competence-based education now adopted in the Netherlands can be described as comprehensive in comparison with more behaviourist and reductionist models of training and learning that were adopted in the USA (Delamare Le Deist and Winterton 2005) in the 1970s and 1980s. Then, the concept of competency was used in a narrower behavioural sense. In contrast to competence, competency is now defined as an underlying attribute (i.e., knowledge, skill, or attitude) of an individual causally related to effective performance in a job (Boyatzis 1982). Describing the jobs of professionals using the concept of competency resulted in detailed lists of fragmented and assessable elements that cannot provide guidelines for curriculum design because of the detailed level of description (Barnett 1994). In contrast with this reductionist approach, competencies in the comprehensive approach are seen as integrated constructs of cognitive, functional, social, and meta-level aspects possessed by individuals, and these constructs can be called competencies only when the individual is able to demonstrate them in relevant situations. So, competencies are integrated (or holistic, as Delamare Le Deist and Winterton (2005) put it) constructs that are a function of the context in which they are applied. Without a context competencies are too generic and have little meaning (Hodkinson and Issitt 1995). This comprehensive approach should be seen as a combination of the so-called input approach and output approach towards competence (see Hoffmann 1999), and a multimethod approach is necessary to measure these competencies (Du Chatenier 2009; Lans 2009).

As a consequence, academic disciplines on their own are no longer sufficient for the development of curricula. Instead, competencies needed in professional practice 
together with core professional problems should be the starting point for competence development or learning. This comprehensive approach in the Netherlands shows a remarkable resemblance to the French approach where the focus is on the individual competence, based on the integration of different forms of knowledge, as well as social and personal faculties (Brockmann et al. 2008). To develop students' competencies, as seen from the comprehensive perspective, educational programs should be revised in many cases. More conventional educational programs tend to aim at transferring knowledge and skills from one person to another. However, when competence development is the ultimate goal, educational programs should include the eight aspects of competence-based education introduced above.

Competence-based education shows remarkable resemblance to constructivism. Constructivist learning environments are characterised by knowledge construction, cooperative learning, self-regulated learning, and working with students engaged in meaningful, authentic problems (Loyens and Gijbels 2008), and these characteristics can be recognised implicitly and explicitly in the eight aspects of competence-based education. Constructivism is an umbrella term for perspectives that share the basic assumption that knowledge is actively constructed by the learner (Birenbaum 2003; Harris and Alexander 1998; Tynjälä 1999). In other words, knowledge is not a product that can be transferred from one person to another, because individuals have to construct it for themselves. Consequently, learning requires self-regulation and the building of conceptual structures often through reflection and abstraction (Von Glasersfeld 1995). Comprehensive competence-based learning environments are seen as being examples of constructivist learning environments. Indeed, ideas from constructivist scholars have influenced ideas about comprehensive competence development and competence-based education (e.g., Wesselink et al. 2007) and probably vice versa.

It follows, therefore, that students in competence-based study programs should be offered the opportunity to develop their competencies in professional settings comparable with settings in which they are going to be employed after graduation. Hence, the interrelation between learning in school and learning in the workplace is an important issue, yet not without problems. The next section of this article describes issues of connectivity between learning in school and learning in the workplace.

\section{Connectivity}

In the Dutch secondary vocational education and training system, learning in the workplace is formalised by the Adult \& Vocational Education Act of 1995, which prescribes that students spend between $20 \%$ and $60 \%$ of their training time in the workplace. However, due more than the Act, learning in the workplace has taken on a pivotal role in education because of educational arguments. Van der Klink (1999) suggested reasons, in addition to financial and efficiency advantages, for the growing attention to learning in the workplace over the past few decades. He concluded that students are more motivated if they see and engage in the practices of the profession in which they are being educated. In this way, students are also offered possibilities to develop their competencies; and the transition to professional 
practice is assumed to become easier if students already have some practical experience. Van der Klink (1999) proposed that spending time in practice is beneficial for students' learning. However, recent studies on the actual learning in the workplace have revealed many concerns about the relation between vocational education and professional practice. Some scholars claim that spending a portion of vocational education time in the workplace does not automatically realise educational enrichment (Hardy and Parent 2003; Eraut 2004; Griffiths and Guile 2003). Furthermore, Hardy and Parent (2003) stated that spending time in professional practice does not necessarily mean: i) that education has been integrated into the work environment; ii) that the students have taken advantage of the learning resources available in the workplace(s); iii) that interrelations between theoretical knowledge and practical experiences have been addressed; nor iv) that the development of skills in problem-solving or the usage of learning experiences in other situations have been encouraged.

Eraut (2004) also highlighted concerns about the interrelation between theoretical knowledge and practical experiences. He questioned whether there is any transfer of knowledge from education to the workplace and vice versa and whether it is possible to talk about 'the' knowledge, at all. However, this likely depends upon what is being referred to as knowledge. According to Bereiter (2002), six different types of knowledge are necessary to become a competent expert: i) statable or declarative knowledge - knowledge in an explicit form, ii) implicit or tacit knowledgeunderstanding through experience, iii) episodic knowledge-memories, episodes, events, or narratives from the past, iv) impressionistic knowledge-feelings and impressions that influence action, v) skills or procedural knowledge-knowing how, and vi) regulative knowledge - principles and ideas that professional groups pursue in order to accomplish their work. Bereiter (2002) emphasised that in high-level expertise these six types of knowledge are not separate, but tightly integrated in their use. Therefore, it is not helpful to claim to develop one or more types of knowledge in school, and the other knowledge types in the workplace. The entire range of knowledge types should be developed in relation to each other, and across both kinds of settings. Therefore, the (learning) activities of students in schools and workplaces should be integrated to enable students to become competent professionals.

Griffiths and Guile (2003) called this process of integration the connectivity between learning activities in school and the workplace. Connectivity has also been referred to as bringing together aspects of the learning process that were previously separated (Tynjälä 2009). Tynjälä (2008) described the connectivity model of Griffiths and Guile (2003) as follows: The core of the model is making a 'reflexive' connection between formal learning (e.g., resulting in statable knowledge) and informal learning (e.g., resulting in implicit knowledge), and between 'vertical' and 'horizontal' learning - the former referring to students' conceptual development, the latter to the development of students' capacity to work in different contexts. The proposal here is to bring students into new situations (i.e., resituate) in which they can learn in a way that requires them to draw upon their formal and conceptual learning. The aim is to develop polycontextual and connective skills, which enable 'boundary crossing' by students (Griffiths and Guile 2003). This development is important because it enables students to work in changing and complex contexts, which is one of the key goals of competence-based education. 
Realising connectivity requires close cooperation between educational institutions and workplaces because these parties are both responsible for students' learning (i.e., formal, informal, vertical, and horizontal learning). Therefore, a central role of schools and training providers is to develop partnerships with workplaces to create environments for learning (Tanggaard 2007). Griffiths and Guile (2003) formulated four practices that can be enacted in these learning environments and through which connectivity can be realised. These four practices are held to make the abstract concept of connectivity more concrete and they can be applied as learning activities that enable students' learning across the different settings. The first practice crucial to all learning is that of thinking. Thinking is characterised as a process guided by procedures or social practices with dialogue and argumentation as central activities. Students should thus make use of the opportunities for dialogue and argumentation in the workplace and in school. The second practice is 'dialogic inquiry'. This practice allows less-experienced people to work appropriately with the given cultural resources by means of assistance from more experienced others, afforded by the environment or the provision of specialist tools to resolve a problem. The third practice is boundary crossing. By this process 'horizontal development' is stimulated through participating in different contexts. The fourth practice is resituating knowledge and skills: seeing an original activity from a new perspective, rather than trying to extract it as general heuristic knowledge from its original context, which is known as transfer. Students, teachers, and workplace training supervisors should be aware of these practices that can be supportive in realising connectivity.

\section{Connectivity in Relation to Competence-Based Education}

One of the main aims of competence-based education is to prepare students to make an easy transition from learning to working in the labour market (Biemans et al. 2004). To realise this aim, the demands are increasing to incorporate learning in professional practice in curricula. Yet, to fully benefit from the presupposed advantages of learning in professional practice, optimisation of the connectivity between learning in school and learning in practice is crucial. In the study discussed here, the theoretical framework of competence-based education described above (see also Wesselink et al. 2007) is used to analyse connectivity in SVET in the life sciences in the Netherlands. Only the aspects of competence-based education concerning instruction (and thus not those concerning curriculum) are considered to be relevant for this analysis. Aspect 3 is not taken into account, because it concerns assessment and, in this study, the learning process is of interest. The following aspects are relevant. Aspect 4 (learning activities should take place in various authentic situations) is relevant, because when students are invited into more than one authentic situation (in this case authentic means professional practice) they are enabled to cross boundaries and reflect on these experiences in the various settings, which makes possible the resituating of knowledge and skills. The sixth and seventh aspect are also important for this process of reflection. Aspect 6 concerns the selfresponsibility of students. They have to report on activities (e.g., dialogues or argumentations of colleagues or teachers) that they regard as meaningful learning activities and that can be used as a starting point for reflection. Aspect 7 concerns the 
role of teachers and workplace training supervisors. Teachers should become more of a coach without losing their role as expert and support students while they are reflecting on meaningful learning activities. Workplace training supervisors increasingly play a role as well in students' reflection on meaningful learning activities instead of only acting as an expert or employer. Reflection on meaningful learning activities can take place both in school and in practice: It is a shared responsibility of teachers, workplace training supervisors, and students. To conclude, these three aspects of competence-based education $(4,6$, and 7 of the theoretical framework) are regarded as relevant for studying the connectivity between learning in school and learning in the workplace.

The intention of this study was to examine the concept of connectivity from a stakeholder point of view. Because learning in the workplace is a multifaceted process, there is no single understanding of learning at work (Boud and Garrick 1999). This stakeholder perspective was also chosen because of the research of Poortman (2007). She concluded that the benefits of workplace learning do not meet the expectations of the different stakeholders because these stakeholders do not fulfil their mutual responsibilities. Considering the three aspects of competence-based education that are related to connectivity, three groups of stakeholders can be identified: students (especially important for Aspect 6), teachers, and workplace training supervisors (especially important for Aspects 4 and 7). These groups of stakeholders all have their own perceptions of the three aspects of competence-based education related to connectivity as realised in educational practice. The central research question of this study is: In what ways do the three aspects of competencebased education (i.e., i) authenticity, ii) self-responsibility, and iii) role of expert and coach) offer footholds to analyse the connectivity between learning in school and learning in the workplace and to improve this connectivity?

\section{Method}

As foreshadowed, competence-based education is a major trend in Dutch vocational education. Because competence-based education is still under construction, it is not yet possible to study the benefits of competence-based education after students have left school. However, the introduction of competence-based education has already led to changes in educational programs and it is interesting to study the developments taking place. In this study the focus was on two educational programs in SVET. The shaded parts in Fig. 1 represent secondary vocational education. In the Netherlands, SVET is characterised by two different learning routes, each leading to the same qualification. The first learning route is the 'practice-based' learning route. In this route, students have a job (including a contract and monthly payment) and attend school for 1 day a week. The second route is the 'school-based' route: Students spend three or 4 days per week in school and the rest of the week is spent in practice. The cases in this study are both examples of the school-based learning route.

The cases reported here concern educational programs offered by one institution for SVET in life sciences. This institution began preparing for competence-based education more than 5 years ago and in the last 2 years has used the above- 
Fig. 1 Overview of the Dutch formal educational system. $\mathrm{GE}=$ General education; $\mathrm{VE}=$ Vocational education

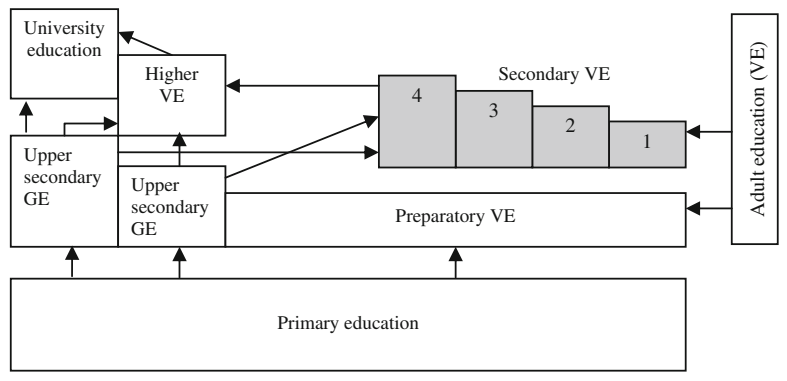

mentioned aspects of competence-based education as starting points for designing (or redesigning) its curricula. This new curricula has been well received and several other institutions in the life sciences have adopted the same competence-based education activities. The institution also aspires to serve as a career guidance centre and a support centre for regional enterprises and organisations that can profit from its expertise. In the Netherlands, this institution is known for its front-runner position when it comes to competence-based education and for this reason was chosen to participate in this research.

The first program selected for this study is called Flowers, a program in which students learn to make and sell flower arrangements. Flowers is offered at all four levels of SVET and students who were in their second year of the third level were included in this study. The second educational program, called Contracting, was chosen because of the diversity of contractors' practice. Contractors in this context are independent professionals (or employees of an organisation) hired by farmers to perform activities on the land that farmers are unable to do themselves because of time restraints or lack of equipment. Examples of such activities are ploughing or fertilising. In this case, students who were in their second year of the second and third level were included.

A general description of these two educational programs is given below, followed by detailed information about the participants and instruments used in this study.

\section{General Description of Flowers Program}

The Flowers curriculum is structured as follows. After a short introduction period, students are prepared for the competence-based education process. The role of the actors in competence-based education is illustrated and the organisation and cooperation between the school and the participating companies are now explained. Students are assessed with respect to competencies they have already mastered. Depending on the results students subsequently participate in the following kinds of learning activities: professional training in internships, selected assignments, practical training, and professional projects (in groups) organised at several points in the school year. These learning activities prepare the students for proficiency tests, which are ill-defined problems in authentic situations that have to be solved by the students. The learning activities are selected jointly by the student, teacher, and workplace training supervisor. Some assignments are carried out in school, others in the workplace during internships. The students work 2 days per week in practice and 
the remaining 3 days in school. Much effort is spent on the students' reflection process in order to stimulate self-responsibility. Students are expected to write weekly reports and discuss these with their teachers and/or coaches.

\section{General Description of Contracting Program}

In the first 2 weeks students acquaint themselves with the school and the company at which they will complete their internship. An important activity in these first weeks is an intake in which the students' competencies are assessed. During the third week, students are informed about learning activities they can do to prepare for their proficiency tests. Students select a set of learning activities and discuss with their workplace training supervisor and their teacher which of these activities are suitable for the workplace and which assignments should be done in school. The students themselves plan when they are going to do which activity. They only have to take into account the final date on which they will take the proficiency test. Teachers try to visit the internship companies three times per year. Throughout the rest of the year, the students work for 2 days in practice and spend the other 3 days in school. Students are asked to write a weekly report reflecting on their experiences.

\section{Participants}

In this study, three different groups of stakeholders were questioned in November and December of 2007: students, teachers, and workplace training supervisors. In total, 25 Contracting students and four Flowers students participated, all of whom were in their second year and between 16 and 18 years of age. In the case of Contracting, all 25 students of one class joined the group interview because the teachers had reserved a specific time for this session. In the case of Flowers, the four selected students were the only ones in their group who had completed an obligatory assignment; for this reason, the sizes of the two groups differed considerably. All 10 teachers involved in Flowers joined the group interview, including those responsible for general subjects such as foreign languages and mathematics. Only two teachers from Contracting joined the group interview - teachers responsible for more general subjects or traditional disciplines were absent. All teachers had several years of teaching experience as well as skills and practice in designing and providing competence-based education. The workplace training supervisors were selected by the teachers because of their involvement in education. Eight workplace training supervisors for Flowers and five for Contracting participated in this study. Because all workplace training supervisors had monitored groups of students before and after the change towards competence-based education, they were capable of comparing the two situations. Table 1 summarises the numbers of respondents per stakeholder group (i.e., students, teachers, and workplace training supervisors) who were interviewed for each program (i.e., Flowers and Contracting).

\section{Group Interviews}

The most prominent stakeholders in competence-based education are students, teachers, and workplace training supervisors. In this study, these three groups of 
Table 1 Numbers of interviewees

\begin{tabular}{lccc}
\hline Programs & Students & Teachers & Workplace training supervisors \\
\hline Flowers & 4 & 10 & 8 \\
Contracting & 25 & 2 & 5 \\
\hline
\end{tabular}

stakeholders were questioned about their experiences with and perceptions of the connectivity between learning in school and learning in the workplace in competence-based education. Group interviews were used in this study. This method was considered to be most suitable since developments with respect to competencebased education are rather new and complex and not suitable to be asked about in questionnaires. In case of an interview clarification could be provided to explain a question if it was not clear. Also, in this way teachers, students, or workplace training supervisors could together determine their interpretation of situations or what is significant about that situation. A disadvantage of this type of questioning is that individual responses are excluded. However, in group interviews the participants have time to think before speaking, so the responses are often more considered than in an individual interview or questionnaire (Krathwohl 1998).

The interviews of all groups can be described as semistructured. The three aspects of competence-based education mentioned above (Aspects 4, 6, and 7; see also Wesselink et al. 2007) were used as starting points for the topics of the interviews. The questions thus concerned authentic situations (Aspect 4); the extent to which students are capable of being responsible for their own learning process (Aspect 6); and the role of supervisors both in school and practice (Aspect 7). The respondents also had the opportunity to talk about related topics. The interviews took approximately $90 \mathrm{~min}$ and were always conducted by two researchers. One researcher asked questions while the other took notes. The answers of all stakeholder groups were compared and analysed in terms of similarities and differences.

\section{Results}

The results are described per educational program and per stakeholder group. The responses of each stakeholder group are structured thematically on the basis of the three aspects: i) authentic situations, ii) self-responsibility, and iii) the role of supervisors. The results are summarised in a table at the end of the results section.

\section{Flowers Program-Students}

Flowers students indicated that they tend to learn most from practical situations in projects both in and outside school. Projects are very popular because results are tangible and students can be proud of their efforts. During projects, students from several school years work together in small teams on assignments from real customers and these authentic conditions stimulate the development of an active and entrepreneurial attitude. 
The students were not satisfied with the start of competence-based education in the school year 2006-2007, claiming that the introduction lacked focus. In the subsequent school year, however, much progress was made, and what and how the students are expected to learn is made more explicit. The students indicated that they learn and work in a more self-responsible way than they were accustomed to when they started their education. Several students stated that competence-based education fits better with their personal learning goals. Others commented that their selfresponsibility in learning is sometimes overrated, which has a negative effect on their learning efforts. Certain basic knowledge should be offered in a more instruction-based way. These students felt that more structure is thus needed in competence-based education. In general, however, the students do not want to return to the traditional or conventional system of vocational education mainly characterised by teaching.

Students experience the administration of their projects and exercises as less functional ("a pile of paperwork") for the actual learning results. They are also convinced that the cooperation between the SVET institution and companies in professional practice should be improved. The school's timetable dictates the possibilities for the students to work as apprentices. Moreover, the teachers' instructions and exercises are not sufficiently adjusted to the professional practice of the companies. According to the students, workplace training supervisors experience some of the exercises as not very realistic. Many exercises are also limited to a few topics, for example styling and design. The students' freedom in selecting learning routes is limited at the moment, because there is only a small set of projects and learning activities available. Finally, competencies are insufficiently aligned with the professional context in the companies. In general, the teachers still decide upon the study program of the students.

\section{Flowers Program-Teachers}

The teachers reported that they have put much effort into creating a portfolio of relevant assignments, training exercises, practical information sources, and databases. Together with colleagues from other SVET institutions in the life sciences they have constructed a back-office of learning activities, called the 'Green Lab'. Practical and authentic learning are the initial starting points. The assignments, training exercises, and practical information sources outline learning activities for the students in order to prepare them for proficiency tests. On the basis of the Green Lab back-office it is possible to compose learning arrangements for each student. Ideally, a learning arrangement should be based on learning questions of the student. However, to achieve more balance and structure in the organisation of the school, many learning activities are compulsory. Neither the student nor the workplace training supervisor composes the learning arrangements-it is the teacher's responsibility. Because of the nature of the intake one might expect individual learning routes. At the moment, however, these are absent.

According to the teachers, the goal of developing a high level of selfresponsibility among the students is not being achieved. As a consequence, continuous involvement of the teachers is necessary. The level of development and motivation of students can be increased by offering them more choices. Practical 
work strongly increases their learning efforts as well. Motivation to learn general subjects, such as foreign languages and mathematics, is enhanced by integrating these subjects into the contexts of jobs and enterprises. Motivation of the students is a critical factor in competence-based education. Students with less self-responsibility and initiative will be less successful in competence-based education.

The teachers are actively involved in improving the internal organisation of the programs in order to facilitate competence-based education. A pitfall is the complex administrative load, which results in a pile of paperwork for teachers, students, and workplace training supervisors alike. At the same time, the curriculum is becoming more transparent. Transparent and concrete pathways to the proficiency tests supported by effective registration of students' achievements and performance may improve the situation. The teachers are proud of their team efforts in the transition towards competence-based education. Factors such as cooperation, energy, and support, even from critical co-developing colleagues, are being recognised as important. Individual teachers are proud of their personal growth and the improvements that have been achieved in education, information and communication technology, and coaching skills.

\section{Flowers Program-Workplace Training Supervisors}

Workplace training supervisors want to be involved in constructing authentic assignments and exercises. According to them, counselling of students should be improved. Workplace training supervisors would appreciate visits from competent and interested teachers, but teachers are usually too busy to fulfil these tasks. According to workplace training supervisors, students are in general less positive about their education than are students of the traditional educational system. According to the workplace training supervisors, competence-based education is suitable only for a minority of the students. The high demands of the workplace cannot be fulfilled by many of them. Competence-based education favours the independent, strong students. Too many students have not been well prepared for working in a company or even for an interview for an apprenticeship. The level of basic knowledge, for instance arithmetic and botanical knowledge, has decreased in general. A customer-oriented attitude and basic social abilities are expected, but many students are also less skilled in this respect.

The cooperation between companies and the SVET institution is still unsatisfactory. Some parts of the educational program and proficiency tests do not fit into the schedule of professional practice. Workplace training supervisors are convinced that teachers are the most important link in bridging the gap between the professional life sciences sector and SVET. Innovations such as competence-based education will not achieve their full effect if teachers do not reconsider and change their position in the educational process. The influence of companies on the educational process should increase. In general, teachers are insufficiently familiar with current activities in professional practice. According to workplace training supervisors, the best possible teacher is the teacher who also works part-time as a professional in an enterprise. Full-time teachers should take a period of retraining in professional practice. It was proposed that the cooperation between the SVET institution and the companies should also be organised in a more flexible way in order to anticipate circumstances 
in professional practice. Currently, students are absent at many important moments in flower shops such as Mother's Day, Valentine's Day, and the Christmas period, so the SVET institution should align its programs to the calendar of the companies to a greater extent. Working and learning together has multiple advantages: Students can learn, companies provide continuity, and competent students can obtain jobs.

\section{Contracting Program-Students}

Students are clear about the tasks they enjoy. Whether in school or in the workplace, they like working with tractors and the authentic setting of a contracting firm is attractive to many of them. Students dislike writing their weekly reports as they have difficulty converting their learning experiences into words. Therefore they do not devote enough time to completing them. These reports could play an important reflective role if the students gave them more attention. Students are required to make a plan of which learning activities they are going to do. They experience this as relatively easy. Thus, according to the students, they can be held responsible for their own planning of the learning activities. However, sticking to their schedule is difficult for them, even in situations in which the workplace training supervisor is informed about their plan. Students reported that they do the job that is required of them by their workplace training supervisor but forget to complete school assignments during busy periods. The students said they would prefer to work in school on these assignments because there they have the time to do so. In this regard, students requested more guidance from the teachers. Furthermore, the students indicated that they can learn a lot just by discovering for themselves or by observing their workplace training supervisors on the job. They expressed that they do not need assignments to study theoretical backgrounds; they prefer to learn by actually doing their job. According to the students, that is enough; "Just let us work in practice".

\section{Contracting Program-Teachers}

Teachers indicated that this way of providing education motivates students. However, a disadvantage of learning in practice or in authentic settings is that some more general competencies and skills remain unnoticed or get attention only in school. In practice, the focus is mainly on competencies and tasks directly related to the profession. Therefore, teachers try with the help of workplace training supervisors to make the students more aware of the importance of these general competencies and skills.

Teachers indicated that, in competence-based education, the role of workplace training supervisors has become more important. If the workplace training supervisors would emphasise that assignments are important, then the students would see the added value. According to the teachers, workplace training supervisors and students are jointly responsible for these assignments. That is the most important role for workplace training supervisors. The teachers indicated that they are in need of relevant assignments that can be carried out in the workplace and a useful set of reference books in which the students can find information themselves. Current facilities are not suitable for competence-based education and are still 'instructionbased', thereby limiting the possibilities for students to be responsible for their own learning process. 
Contracting Program-Workplace Training Supervisors

Workplace training supervisors mentioned that students should ask more questions than they currently do. Students should not have the idea that they are just there to work hard and show their capacities. Although proving one's capabilities may enhance the chance of securing a job, students must be aware that this should not happen at the expense of the learning process. The workplace training supervisors reported being satisfied with the fact that students have to participate in an intake. This provides workplace training supervisors with information that can be used during the practical training. Workplace training supervisors are also satisfied with the regular visits of the teachers, as this makes it easier to agree upon assignments that can be done in the enterprise. That is a clear role for the teachers. However, workplace training supervisors revealed two important drawbacks of the current situation with respect to their own role and the self-responsibility of the students. Students only occasionally inform workplace training supervisors about their learning activities. The workplace training supervisors think students do not allow themselves enough time to work on the assignments, because they believe they have to be continuously profitable for the company. That is strange, because all workplace training supervisors claim to emphasise the importance of creating a climate in which the students feel they have enough time to work on the school assignments. All workplace training supervisors share the opinion that students should be invited to the enterprise to learn things and not just to work. Not knowing the students' learning activities makes it difficult for workplace training supervisors to coach the students in completing the assignments. Moreover, workplace training supervisors think that the assignments are not always sufficiently clear. Table 2 summarises the results of this study as reported above. The table shows per program a summary of the responses of each stakeholder group (i.e., students, teachers, and workplace training supervisors) per relevant aspect of competence-based education and makes it possible to compare the responses of the different stakeholder groups.

\section{Conclusion and Discussion}

The developments in competence-based education in Dutch vocational education in life sciences are described in relation to the problems concerning connectivity between learning in school and learning in the workplace. The importance of workplace learning is increasing through the implementation of competence-based education, but the relation between learning in the workplace and learning in school still does not meet the expectations. According to the connectivity theory of Griffiths and Guile (2003), connectivity between learning in the workplace and learning in school should be realised to provide the necessary support for students to become competent professionals. However, the question remains how connectivity can be realised. In this article, the following research question was formulated: Do three specific aspects of competence-based education (i.e., authenticity, self-responsibility, and role of expert and coach) offer footholds to analyse the connectivity between learning in school and learning in the workplace and to improve this connectivity? The following stakeholder groups were consulted in this study: students, teachers, 
Table 2 Summary of conceptions per stakeholder group and per relevant aspect of competence-based education

\begin{tabular}{|c|c|c|c|c|}
\hline & & Aspect 4 & Aspect 6 & Aspect 7 \\
\hline & & Authentic situations & Self-responsibility & Role of supervisors \\
\hline \multirow[t]{3}{*}{ Flowers } & Students & $\begin{array}{l}\text { Competence-based } \\
\text { education brings core } \\
\text { professional tasks into } \\
\text { the educational process. }\end{array}$ & $\begin{array}{l}\text { Self-responsibility } \\
\text { should be gradually } \\
\text { obtained in a } \\
\text { controlled way. }\end{array}$ & $\begin{array}{l}\text { Teachers should provide } \\
\text { more structure in the } \\
\text { learning process. }\end{array}$ \\
\hline & Teachers & $\begin{array}{l}\text { Competence-based } \\
\text { education can only be } \\
\text { developed in a team. } \\
\text { Competence-based } \\
\text { education requires } \\
\text { organisational skills. }\end{array}$ & $\begin{array}{l}\text { The development of self- } \\
\text { responsibility of the } \\
\text { students is currently } \\
\text { insufficient and should } \\
\text { be increased. }\end{array}$ & $\begin{array}{l}\text { Starting point for } \\
\text { realising competence- } \\
\text { based education is the } \\
\text { internal organisation } \\
\text { of the school. }\end{array}$ \\
\hline & $\begin{array}{l}\text { Workplace } \\
\text { training } \\
\text { supervisors }\end{array}$ & $\begin{array}{l}\text { Workplace training } \\
\text { supervisors should be } \\
\text { more involved in the } \\
\text { educational process, } \\
\text { e.g. in constructing } \\
\text { assignments and } \\
\text { training teachers. }\end{array}$ & $\begin{array}{l}\text { Self-responsibility } \\
\text { currently appears to } \\
\text { favour strong students: } \\
\text { only they will succeed. }\end{array}$ & $\begin{array}{l}\text { Teachers should break out } \\
\text { of the school system and } \\
\text { put the core professional } \\
\text { tasks of the workplace } \\
\text { training supervisors- } \\
\text { companies in a central } \\
\text { position. }\end{array}$ \\
\hline \multirow[t]{3}{*}{ Contracting } & Students & $\begin{array}{l}\text { Working in practice is the } \\
\text { most motivating part of } \\
\text { education. Students say } \\
\text { they learn from working } \\
\text { in practice. }\end{array}$ & $\begin{array}{l}\text { Students consider } \\
\text { themselves able to make } \\
\text { a plan learning activities, } \\
\text { but they experience } \\
\text { difficulties sticking to } \\
\text { that plan. }\end{array}$ & $\begin{array}{l}\text { The teacher should help } \\
\text { students plan their } \\
\text { learning activities. } \\
\text { Workplace training } \\
\text { supervisors are role } \\
\text { models. }\end{array}$ \\
\hline & Teachers & $\begin{array}{l}\text { More general disciplines } \\
\text { may not receive } \\
\text { enough attention } \\
\text { during learning in } \\
\text { the workplace. }\end{array}$ & $\begin{array}{l}\text { Current assignments } \\
\text { are too focussed on } \\
\text { instruction-based } \\
\text { learning and do not } \\
\text { facilitate the self- } \\
\text { responsibility of } \\
\text { the students. }\end{array}$ & $\begin{array}{l}\text { Workplace training } \\
\text { supervisors together } \\
\text { with students are } \\
\text { responsible for } \\
\text { realising assignments. }\end{array}$ \\
\hline & $\begin{array}{l}\text { Workplace } \\
\text { training } \\
\text { supervisors }\end{array}$ & $\begin{array}{l}\text { Students get the chance } \\
\text { to learn while working } \\
\text { in practice; they are } \\
\text { not seen as personnel. }\end{array}$ & $\begin{array}{l}\text { Students should be made } \\
\text { aware of the fact that } \\
\text { it is their responsibility } \\
\text { to learn. }\end{array}$ & $\begin{array}{l}\text { Teachers should visit } \\
\text { the companies to agree } \\
\text { upon the assignments } \\
\text { to be done. }\end{array}$ \\
\hline
\end{tabular}

and workplace training supervisors. The three aspects of competence-based education were the basis of the questions asked of the three stakeholder groups and the analysis of their different points of view.

All stakeholders recognise the growing attention being paid to learning in the workplace as observed by Van der Klink (1999) and they are convinced of the added value of learning in the workplace; problems and questions put forward relate to 'how' learning in the workplace can support the learning process and not 'whether' learning in the workplace should be part of the educational program. Students in particular indicated that they really like learning in the workplace; learning by doing is their preference. Teachers still have some doubts (e.g., about whether all disciplines are sufficiently taught in this way and to what extent students can be responsible for their own learning), but they recognise that working in professional practice motivates the students. Workplace training supervisors indicated that they 
would be happy to see teachers visit the workplaces more often. Furthermore, in their opinion, teachers should incorporate in the educational programs of students learning tasks that are more relevant for professional organisations. Finally, they would like to see that decisions are made jointly about which assignments will be done in school and which will be done in the workplace.

It is remarkable that the stakeholder groups have different conceptions of learning in the workplace. Students regard learning in the workplace mainly as working, whereas workplace training supervisors and teachers see learning in the workplace mainly as learning. Both teachers and workplace training supervisors interpret workplace learning more as guided learning (learning by means of specific assignments), whereas students see workplace learning more as experiential learning (learning by doing; see Simons et al. 2000). A possible consequence of these different conceptions could be that agreements are interpreted differently. Furthermore, students do not recognise all possible learning activities as such. Jobperformance activities and participation in practice are activities they recognise as learning activities. However, the learning environment offers many more meaningful learning opportunities, such as social interaction, imitation, and transmission (Poortman 2007). Students have to be made aware of all these possible learning activities by their teachers and workplace training supervisors.

Another noteworthy issue concerns responsibility for the learning process in the workplace (see also Poortman 2007). According to the workplace training supervisors, the teachers should be primarily responsible for the learning activities and, therefore, also for the learning process in the workplace. According to the Contracting teachers, however, the workplace training supervisors together with the students are responsible for the learning process in the workplace. Students see themselves as being more and more responsible for their own learning process; they want to define their own learning goals, plan their own learning activities, and only if necessary ask a teacher or workplace training supervisor for support. However, both teachers and workplace training supervisors expressed doubts about the extent to which the students are really able to be self-responsible. As long as the different groups involved in workplace learning do not share mutual expectations about responsibility, this aspect will remain a problem. Without clear agreements between all parties involved about mutual responsibilities it will be difficult to realise connectivity.

The three aspects of competence-based education examined in this study appeared to be useful as footholds to provide insight into issues of connectivity. The most important concerns in this respect are the different conceptions held by the various stakeholder groups of what learning in the workplace entails and the lack of agreement on the division of responsibilities for learning in the workplace. Stakeholders should be aware of the different conceptions of workplace learning (guided vs. experiential learning). Students may not recognise all of the possible learning opportunities in the workplace, because of their conception of learning in the workplace. This has consequences for reflection processes. During reflection processes students should be made aware that a discussion with the workplace training supervisor or another colleague can also be seen as a learning activity. Teachers and workplace training supervisors together are responsible for this reflection and for bridging the gap between theory learned in school (or in other contexts) and experiences in practice. Students themselves are hardly able to make the 
connection between what is learned in school and in practice, because they mainly 'work' in practice. For most students in the case studies, reflection is not part of their learning process because of their learning-by-doing approach. Teachers and workplace training supervisors have to challenge the students to think about the things that they have done and learned. Teachers are responsible for the students' competence development process as a whole, because different workplace training supervisors are involved in the students' learning process and that makes it difficult for them to cross boundaries with students.

Griffiths and Guile (2003) approached connectivity from the perspective of the learning process and defined practices that could improve connectivity. However, this article proposes that the conceptions of workplace learning and the responsibilities of the various stakeholders for the learning process in the workplace should be taken into account in the connectivity model as well. These two issues will have to be dealt with before concrete workplace learning activities like dialogic inquiry and border crossing can show their added value. This study illustrates that the abovementioned aspects of competence-based education can offer footholds to analyse the connectivity between learning in school and learning in the workplace; however, this does not guarantee an improvement of connectivity. To realise improvement stakeholders should determine their mutual responsibilities and they should clarify their points of view on workplace learning. Based on the three aspects of competence-based education used as a starting point for this study, the following recommendations can be made. First, clear agreements should be formulated on which learning or working activities should take place in which setting (Aspect 4). Second, the stakeholders should be made aware of each other's views on workplace learning. Finally, the stakeholders should share each other's expectations concerning mutual responsibilities (Aspect 6) and which roles the teacher and workplace training supervisor should fulfil in this learning process (Aspect 7). Because of the resemblance of competence-based education to learning environments developed on the basis of constructivist viewpoints, these recommendations can probably also be supportive for the design of constructivist learning environments.

This study took place in the context of SVET in the Netherlands. However, the development towards competence-based education is also taking place in other segments of the vocational education sector and, therefore, the expectation is that the results of this study also apply to other segments of the vocational education system in the Netherlands as well as in other countries (see also Biemans et al. 2009). However, it remains difficult to make statements about how representative the results and conclusions of this study are. In further research the numbers of students, teachers, and workplace training supervisors to be questioned should be increased to get a more general picture. A more qualitative approach could also be applied and in that case it would be interesting to have a closer look at the actual (reflection) conversations between student and teacher and between student and workplace training supervisor.

Connectivity between learning in the workplace and learning in school has been a concern for many decades. Because of the introduction and implementation of competence-based education, the expectations about learning in the workplace have been increasing and the same is true for the importance of connectivity between learning in school and learning in the workplace. The three aspects of competencebased education used in this study (authenticity, self-responsibility, and role of expert and coach) appeared to offer the opportunity to take a closer look at connectivity 
issues, and if the conclusions addressed in this study are taken into account in the interaction between students, teachers, and workplace training supervisors, the findings can have a positive impact on improving connectivity in the near future.

Acknowledgement This research was made possible by the involvement and commitment of the students, teachers, and workplace training supervisors of AOC Oost. The authors would like to thank these persons for their contributions.

Open Access This article is distributed under the terms of the Creative Commons Attribution Noncommercial License which permits any noncommercial use, distribution, and reproduction in any medium, provided the original author(s) and source are credited.

\section{References}

Arguelles, A., \& Gonczi, A. (eds). (2000). Competency based education and training: A world perspective. Balderas: Editorial Limusa S.A. de C.V. Grupo Noriego Editores.

Barnett, R. (1994). The limits of competence: Knowledge, higher education and society. Buckingham: Open University Press.

Bastiaens, Th, \& Martens, R. (2003). ICT en competentiegericht onderwijs. In M. Mulder, R. Wesselink, H. Biemans, L. Nieuwenhuis \& R. Poell (Eds.), Competentiegericht beroepsonderwijs. Gediplomeerd, maar ook bekwaam? (pp. 199-214). The Netherlands: Wolters-Noordhoff.

Bereiter, C. (2002). Education and mind in the knowledge age. Mahwah: Erlbaum.

Biemans, H., Nieuwenhuis, L., Poell, R., Mulder, M., \& Wesselink, R. (2004). Competence-based VET in the Netherlands: background and pitfalls. Journal of Vocational Education and Training, 56(4), 523-538.

Biemans, H., Wesselink, R., Gulikers, J., Schaafsma, S., Verstegen, J., \& Mulder, M. (2009). Towards competence-based VET: dealing with the pitfalls. Journal of Vocational Education and Training, 61 (3), 267-286.

Birenbaum, M. (2003). New insights into learning and teaching and their implications for assessment. In M. Segers, F. Dochy \& E. Cascallar (Eds.), Optimising new modes of assessment: In search for qualities and standards (pp. 13-36). Dordrecht: Kluwer Academic.

Boud, D., \& Garrick, J. (1999). Understanding learning at work. New York: Routledge.

Boyatzis, R. E. (1982). The competent manager: A model for effective performance. New York: Wiley.

Brockmann, M., Clarke, L., Méhout, P., \& Winch, C. (2008). Competence-based vocational education and training (VET): the cases of England and France in a European perspective. Vocations and Learning, $1,227-244$.

Brouwer, N., \& Korthagen, F. (2005). Can teacher education make a difference? American Educational Research Journal, 42(1), 153-224.

de Bruijn, E., Overmaat, M., Glaude, M., Heemskerk, I., Leemand, Y., \& Roeleveld, J. (2005). Krachtige leeromgevingen in het middelbaar beroepsonderwijs: vormgeving en effecten. Pedagogische Studiën, $82(1), 77-95$.

Delamare Le Deist, F., \& Winterton, J. (2005). What is competence? Human Resource Development International, 8(1), 27-46.

$\mathrm{du}$ Chatenier, E. (2009). Open innovation competence. Towards a competence profile for interorganizational collaboration in innovation teams. $\mathrm{PhD}$ dissertation: Wageningen University.

Eraut, M. (2004). Transfer of knowledge between education and workplace settings. In H. Rainbird, A. Fuller \& A. Munro (Eds.), Workplace learning in context (pp. 201-221). London: Routledge.

Griffiths, T., \& Guile, D. (2003). A connective model of learning: the implications for work process knowledge. European Educational Research Journal, 2(1), 56-73.

Gulikers, J. (2007). Authenticity in the eye of the beholder. Beliefs and perceptions of authentic assessment. Heerlen: Open University.

Hardy, M., \& Parent, C. (2003). School-workplace collaboration: An uneasy partnership_Experiences from two alternation programs in Quebec. In H. G. Schuetze \& R. Sweet (Eds.), Integrating school and workplace learning in Canada: Aspects and 20 practices of alternation education and training (pp. 135-156). Montreal \& Kingston: McGill-Queens University Press.

Harris, K. R., \& Alexander, P. A. (1998). Integrated, constructivist education: challenge and reality. Educational Psychology Review, 10, 115-127. 
Hodkinson, P., \& Issitt, M. (1995). The challenge of competence: Professionalism through vocational education and training. London: Cassell.

Hoffmann, T. (1999). The meanings of competency. Journal of European Industrial Training, 23(6), 275285.

Jenewein, K., Knauth, P., \& Zülch, G. (2002). Kompetenzentwicklung in unternehmensprozessen. Aachen: Shaker.

Krathwohl, D. R. (1998). Methods of educational and social science research: An integrated approach (2nd ed.). New York: Longman.

Lans, T. (2009) Entrepreneurial competence in agriculture. Identification, development and the role of the work environment. $\mathrm{PhD}$ dissertation: Wageningen University.

Loyens, S. M. M., \& Gijbels, D. (2008). Understanding the effects of constructivist learning environments: introducing a multi-directional approach. Instructional Science, 36(5-6), 351-357.

Mulder, M. (2004). Educatie, competentie en prestatie: Over opleiding en ontwikkelingin het agrofoodcomplex. Wageningen: Wageningen University.

Mulder, M. (2007). Competence-The essence and use of the concept in ICVT. European Journal of Vocational Training, 40, 5-22.

Mulder, M., Weigel, T., \& Collins, K. (2007). The concept of competence in the development of vocational education and training in selected EU member states. A critical analysis. Journal of Vocational Education and Training, 59(1), 65-85.

Perels, F., Gürtler, T., \& Schmitz, B. (2005). Training of self-regulatory and problem solving competence. Learning and Instruction, 15(2), 123-139.

Poortman, C. (2007). Workplace learning processes in senior secondary vocational education. $\mathrm{PhD}$ dissertation: University of Twente.

Simons, P. R. J., van der Linden, J., \& Duffy, T. (2000). New learning: Three ways to learn in a new balance. In P. R. J. Simons, J. van der Linden \& T. Duffy (Eds.), New learning (pp. 1-20). Dordrecht: Kluwer Academic.

Stoof, A., Martens, R. L., van Merriënboer, J. J. G., \& Bastiaens, T. J. (2002). The boundary approach of competence: a constructivist aid for understanding and using the concept of competence. Human Resource Development Review, 1(3), 345-365.

Tanggaard, L. (2007). Learning at trade vocational schools and learning at work: boundary crossing in apprentices' everyday life. Journal of Education and Work, 20(5), 453-466.

Ten Dam, G., \& Volman, M. (2004). Critical thinking as a citizenship competence: teaching strategies. Learning and Instruction, 14(4), 359-379.

Tynjälä, P. (1999). Towards expert knowledge? A comparison between a constructivist and a traditional learning environment in the University. International Journal of Educational Research, 33, 355-442.

Tynjälä, P. (2008). Perspectives into learning at the workplace. Educational Research Review, 3, $130-154$.

Tynjälä, P. (2009). Connectivity and transformation in work-related learning-Theoretical foundations. In M. L. Stenström \& P. Tynjälä (Eds), Towards integration of work and learning (11-39). Springer Science + Business Media B.V.

van den Berg, N., \& de Bruijn, E. (2009). Het glas vult zich. Kennis over vormgeving en effecten van competentiegericht beroepsonderwijs; verslag van een review. Amsterdam/'s Hertogenbosch: ECBO.

van der Klink, M. R. (1999). Effectiviteit van werkplekopleiden. PhD dissertation. University of Twente.

van der Klink, M. R., Boon, J., \& Schlusmans, K. (2007). Competences and vocational higher education: now and in future. European Journal Vocational Training, 40(1), 67-82.

Von Glasersfeld, E. (1995). A constructivist approach to teaching. In L. P. Steffe \& J. Gale (Eds.), Constructivism in education (pp. 3-17). New Jersey: Lawrence Erlbaum Associates.

Wesselink, R., Biemans, H. J. A., Mulder, M., \& Van den Elsen, E. (2007). Competence-based VET as seen by Dutch researchers. European Journal Vocational Training, 40(1), 38-51.

Drs. Renate Wesselink is an assistant professor in the Education and Competence Studies group in the Department of Social Sciences, Wageningen University, The Netherlands.

Drs. Cees de Jong is senior consultant at CPS Education Development and Advice.

Dr. Harm J.A. Biemans is an associate professor in the Education and Competence Studies group in the Department of Social Sciences, Wageningen University, The Netherlands. 